\title{
INTERPRETASI E-LEARNING SEBAGAI SUPPORT MEDIA UNTUK PEMBELAJARAN BAHASA MANDARIN BAGI SISWA SEKOLAH DASAR
}

\author{
Yulius Hari $^{{ }^{*} \text {, Darmanto Aspali }}{ }^{1}$ Budi Hermawan ${ }^{2}$ \\ ${ }^{1}$ Jurusan Teknik Informatika, Universitas Widya Kartika Surabaya \\ ${ }^{2}$ Jurusan Bahasa dan Sastra Mandarin, Universitas Widya Kartika, Surabaya \\ Telp: (031) 5922403, Fax : (031) 5925790 \\ E-mail: yulius.hari.s@gmail.com, darmanto2@hotmail.com, budi_bh1@yahoo.co.id \\ *Korespondensi penulis
}

\begin{abstract}
Abstrak: Di Indonesia, kebutuhan akan kemampuan bahasa Mandarin sudah mulai terlihat. Banyak sekolah saat ini sudah melibatkan bahasa Mandarin dalam kurikulumnya, termasuk Sekolah Dasar (SD). Sementara itu permasalahan utama dalam pembelajaran bahasa Mandarin adalah bentuk intonasi ataupun pelafalan yang jauh berbeda dengan bahasa Indonesia yang tidak memperhatikan nada. Dalam kurikulum pelajaran bahasa Mandarin tingkat SD, khususnya kelas tiga ke atas, siswa diharapkan mampu mendengarkan, menyebutkan, membaca dan menulis bilangan. Pembelajaran mengenal angka Mandarin dimulai dari bilangan dasar dan dapat diaplikasikan pada penyebutan nomor telepon. Selanjutnya materi ini bertahap pada penyebutan bilangan dengan skala ratusan atau lebih sering kemampuan pelafalan dan kelas siswa. Penggunaannya dalam operasi dasar aritmetika untuk kehidupan sehari-hari seperti halnya dalam penyebutan waktu dan keperluan berbelanja. Pembelajaran aritmetika dalam bahasa Mandarin relatif cukup susah, karena selain mampu melafalkan bilangan dengan benar, siswa harus mampu berhitung dengan tepat.Mengingat keterbatasan media cetak adalah tidak mampu mengakomodasi pembelajaran dalam mendengarkan khususnya pelafalan atau intonasi dengan benar. Hal ini menyebabkan timbulnya gap antara informasi pada buku teks dengan apa yang dipersepsikan oleh pembelajar. Penelitian ini mencoba untuk menjembatani keterbatasan tersebut dengan mengakomodasi media pembelajaran berbasis web yang juga melatih kemampuan dalam mendengarkan, sehingga gap antara informasi pada buku dengan pembelajar dapat direduksi. Hasil penelitian ini diharapkan mampu memberikan alternative baru sebagai model pembelajaran khususnya untuk bahasa Mandarin di Indonesia.
\end{abstract}

Kata kunci: Multimedia learning,, E-learning, spatial contiguity, Language learning

\begin{abstract}
Nowadays, many schools are teaching the Chinese Language as curriculum, including elementary school. While the major problems in Chinese language learning is a form of pronunciation or intonation that much different from the Indonesia language who does not pay attention to the tone. In the Chinese language curriculum students are expected to be able to listen, to pronounce, to read and to write. Furthermore, learning arithmetic subject in Chinese language is quite difficult, because besides being able to pronounce the numbers correctly, the student should be able to count it. Hence the limitations of print media is not able to accommodate learning in listening, especially pronunciation or intonation correctly and also the writing. This led to the emergence of the spatian contiguity between text books with information on what is perceived by the learner. This study attempts to bridge these limitations by accommodating a media in web-based learning that also train the ability to listen and write, so that the spatial distance between the information in the book with a learner can be reduced. The results of this study are expected to provide a new alternative as a model for Chinese language learning, especially in Indonesia.
\end{abstract}

Keywords: Multimedia learning,, E-learning, spatial contiguity, Language learning.

\section{PENDAHULUAN}

Bahasa Mandarin saat ini telah diakui sebagai salah satu bahasa resmi dari PBB. Bahasa ini juga termasuk sebagai bahasa yang memiliki jumlah petutur asli terbesar di dunia. Pesatnya perkembangan ekonomi dan industry di China [3] selama beberapa decade ini membuat bahasa Mandarin semakin diminati sebagai bahasa bisnis dan budaya [1]. Kenyataan tersebut membuat bahasa Mandarin kini menjadi bahasa International kedua yang paling banyak diminati setelah bahasa Inggris.

Di Indonesia, perkembangan dari bahasa asing khususnya Mandarin selama dekade terakhir ini 
sangat pesat. Saat ini banyak sekolah mulai tingkat dasar sampai menengah telah memasukkan pelajaran bahasa asing dan salah satunya adalah bahasa Mandarin ke dalam kurikulum resmi sekolah. Bahkan beberapa sekolah dasar menjadikannya sebagai muatan lokal dalam kurikulumnya. Tetapi dengan terbatasnya waktu tatap muka di kelas dan waktu pembelajaran yang sempit, serta sering kali perbedaan kurikulum antar jenjang institusi menjadikan proses pembelajaran bahasa Mandarin menjadi sulit. Keterbatasan media pembelajaran terutama dalam penuturan intonasi menjadi salah satu masalah tersendiri dalam proses belajar bahasa tersebut [4]. Hal inilah yang menyebabkan timbulnya gap antara informasi pada buku teks dengan apa yang dipersepsikan oleh pembelajar [11], sehingga seringkali pembelajar salah menginterpretasikan pelafalan hanya dari model media cetak.

Sama dengan tujuan kompetensi pembelajaran bahasa asing yang lain, dalam bahasa Mandarin, pembelajar atau siswa dituntut untuk mampu menguasai empat kemampuan dasar berbahasa yang meliputi keterampilan mendengar, berbicara, membaca dan menulis [13]. Ditilik dari jenisnya bahasa Mandarin adalah bahasa nada sehingga kompetensi utama dalam menginterpretasikan pendengaran dan berbicara harus memperhatikan intonasi dan pelafalan. Sebab perbedaan intonasi dan pelafalan memiliki arti dan makna yang berbeda [7], hal inilah yang sering menjadikan pembelajaran bahasa Mandarin sangat sulit di Indonesia dimana bahasa nasional Indonesia tidak memperhatikan intonasi maupun pelafalan.

Sementara itu pembelajaran aritmetika di sekolah dasar sekalipun sudah menjadi semacam "mimpi buruk" tersendiri bagi para siswa.[14] Hal ini diperuncing dengan model pembelajaran yang konvensional sehingga membuat pembelajaran dalam hal aritmetika menjadi sangat monoton dan kurang atraktif.

Di lain pihak, Teknologi Informasi dan Komunikasi (TIK) berkembang sedemikian pesatnya dan aplikasinya menunjang kebutuhan suatu organisasi. Dalam dunia pendidikan, pemanfaatan perangkat TIK sangat membantu proses belajar mengajar. [9]. Metode pembelajaran yang ditunjang dengan TIK memberikan suasana belajar yang berbeda. Demikian halnya dalam belajar bahasa Mandarin maupun aritmetika. Mengingat materi bahasa Mandarin yang cukup unik baik dari segi tulisan, ucapan dan nada yang cukup bervariasi. Sehingga bentuk pembelajaran atau permainan interaktif bahasa Mandarin sangat membantu dalam memahami materi tersebut.[10]

Berdasarkan pemaparan diatas penelitian ini bertujuan untuk memberikan suatu model pem- belajaran yang lebih atraktif dan interaktif serta menggabungkan kedua jenis pembelajaran yaitu bahasa Mandarin yang dikhususkan secara spesifik untuk melatih aritmetika. Dari sistem yang terbentuk akan diuji cobakan lebih lanjut, kemudian dari hasil sampling berkatian dengan kemampuan adaptasi siswa dalam menerima teknologi ini akan diukur menggunakan model Technology Acceptance Model (TAM) yang diuji menggunakan model Structural Equation Model (SEM). Hasil dari penelitian ini diharapkan mampu memberikan suatu mediasi baru dalam pembelajaran yang dikhususkan untuk siswa sekolah dasar, sehingga mampu mendukung dan mampu mendorong motivasi belajar kepada pembelajaran sepanjang hayat (lifelong learning) [5].

\section{LANDASAN TEORI}

Berikut ini akan dijabarkan beberapa landasan teori yang dipergunakan dalam penelitian ini. Adapun landasan teori yang dimaksud meliputi pokok bahasan dalam pembelajaran bahasa Mandarin, dan sistem E-learning sebagai model konseptual dalam penelitian ini yang menjadi media dalam membantu menginterpretasikan sistem.

\section{Pembelajaran dalam Bahasa Mandarin}

Sama dengan tujuan kompetensi pembelajaran bahasa asing yang lain, dalam bahasa Mandarin, pembelajar atau siswa dituntut untuk mampu menguasai empat kemampuan dasar berbahasa yang meliputi ketrampilan mendengar, berbicara, membaca dan menulis. Ditilik dari jenisnya bahasa Mandarin adalah bahasa nada sehingga kompetensi utama dalam menginterpretasikan pendengaran dan berbicara harus memperhatikan intonasi dan pelafalan. Sebab perbedaan intonasi dan pelafalan memiliki arti dan makna yang berbeda, hal inilah yang sering menjadikan pembelajaran bahasa Mandarin sangat sulit di Indonesia. Ada empat jenis nada dalam bahasa Mandarin [16] dan dapat dilihat pada table 1.

Tabel 1. Komparasi Perbedaan Nada Dan Makna

\begin{tabular}{cccc}
\hline No & Nada & Pinyin dan Hanzi & Arti \\
\hline 1. & 第一声 & yī (一) & Satu \\
2. & 第二声 & yí (姨) & Bibi \\
3. & 第三声 & yǐ (椅) & Kursi \\
4. & 第四声 & yì (艺) & Seni \\
\hline
\end{tabular}

Selain memperhatikan nada, dalam bahasa mandarin juga harus memperhatikan pelafalan. Hàn yǔ pīn yīn adalah fonetik yang digunakan di China, yang merupakan standar Internasional pelafalan bahasa Mandarin. Hàn yǔ pīn yīn telah diakui dan 
dipakai di seluruh negara, baik di Asia, Amerika, maupun Eropa. Hàn yǔ pīn yīn lebih efektif membantu pengajaran pelafalan aksara Hanzi bagi pembelajar dengan latar belakang bahasa yang menggunakan huruf alphabet [6]. Tabel 2. dan Tabel 3 menyajikan bentuk konsonan dan vokal dalam bahasa Mandarin.

Tabel 2. Konsonan /声母(Shēng Mǔ) [6]

\begin{tabular}{c|c|c|c|c|c|c|c|c|c|c|c}
\hline $\mathrm{b}$ & $\mathrm{p}$ & $\mathrm{m}$ & $\mathrm{f}$ & $\mathrm{d}$ & $\mathrm{t}$ & $\mathrm{n}$ & $\mathrm{l}$ & $\mathrm{g}$ & $\mathrm{k}$ & $\mathrm{h}$ & $\mathrm{j}$ \\
\hline $\mathrm{q}$ & $\mathrm{x}$ & $\mathrm{zh}$ & $\mathrm{ch}$ & $\mathrm{sh}$ & $\mathrm{r}$ & $\mathrm{z}$ & $\mathrm{c}$ & $\mathrm{s}$ & & & \\
\hline
\end{tabular}

Table 3. Vokal /韵母(Yùn Mǔ) [6]

\begin{tabular}{c|c|c|c|c|c|c|c|c|c}
\hline a & o & e & ê & er & i & u & u & ai & \\
\hline ei & ao & ou & an & ang & ia & ie & io & iao & iou \\
\hline ian & in & iang & i(e)ng & iong & ua & uo & uai & uang & \\
\hline uei & uan & uen & ueng & ue & uan & un & en & eng & ong \\
\hline
\end{tabular}

Dalam bahasa Mandarin, ada kemiripan dalam pelafalan tetapi berbeda dalam intonasi, hal inilah yang kadang membingungkan pembelajar. Sebagai contoh dalam bahasa Mandarin: 这是十四狮子, 不是四十狮子 (zhè shì shí sì shī zi, bú shì sì shí shī zi. Dimana berarti ada empat belas ekor singa, dan bukan empat puluh singa. Dalam contoh kalimat tersebut terdiri dari kata 是(shì), 十 (shí), 四(sì) dan 狮(shī). Di antara keempat kata tersebut pelafalannya hampir sama, yakni shi dan si, tapi dengan intonasi yang berbeda. Di samping itu juga perlu diketahui bahwa ada beberapa karakter Hanzi yang memiliki dua cara baca dengan arti yang berbeda, misalnya: 落 dapat dibaca lào (arti : luntur) dan luò (arti : jatuh), 给dapat dibaca gěi (arti : memberi) dan jǐ (arti : menyuplai).

Atas penjelasan tersebutlah seringkali sangat susah untuk pembelajar bahasa asing khususnya para siswa sekolah dasar untuk mampu mengerti dan menginterpretasikan apa yang diucapkan oleh pengajarnya. Terlebih lagi apabila digabungkan dengan materi pengajaran mengenai aritmetika. Apabila tidak ada media yang mampu menjadi mediasi dalam memahami jarak spasial tersebut dapat dipastikan kurang atau hilangnya motivasi untuk mempelajari hal tersebut [15].

\section{E-learning dan Teknologinya}

Sementara itu pesatnya perkembangan teknologi informasi dan komunikasi (TIK) juga mulai merambah ke ranah pendidikan. Peran TIK disini adalah sebagai media supplementer ataupun penunjang daripada proses belajar mengajar. E-learning merupakan salah satu contoh dari TIK di ranah pendidikan. E-learning sendiri dapat diklasifikasikan sebagai subset dari distance learning, dimana lebih menitik beratkan pada kemudahan dari sisi akses informasi tanpa terkendala pada suatu tempat dan waktu tertentu (ubiquitous learning) [11, 12].

Model pembelajaran E-learning, mengacu pada model pembelajaran jarak jauh dengan memanfaatkan portable technologies sebagai medianya [9, 12]. Dalam hal ini media dari E-learning tidak terbatas hanya pada stand alone komputer personal, tetapi juga dapat berupa notebook, tablet, PDA, dan semua perangkat yang mampu terhubung ke dalam jaringan internet. Sedangkan jenis komunikasi yang mendukung pada perangkat tersebut dapat berupa model GPRS, EDGE, HSDPA, EDVO, Wifii dan sebagainya [12].

Hal ini menjadikannya sebagai suatu model pembelajaran yang unik dimana mampu memberikan sebuah media pembelajaran yang pervasive yang mampu memberikan media pembelajaran seperti visual dan audio sensing dengan mudah dan cepat. Kebiasaan ini mampu mendobrak kebiasaan lama sistem pembelajaran di sekolah yang mewajibkan siswa untuk tetap diam pada satu tempat yang sama dalam waktu tertentu. [2].

\section{PERMODELAN SISTEM}

Pada bagian ini akan dijelaskan mengenai metodologi penelitian yang terbagi menjadi model sistem dan juga model pembelajaran yang dibangun.

\section{Model Sistem}

Model sistem pembelajaran aritmatika dalam bahasa mandarin ini menggunakan tahapan dalam model Sistem Development Life Cycle (SDLC) dengan tahap perencanaan, analisa, desain, uji coba dan implementasi seta uji coba. Penelitian ini sedang berjalan dalam tahap permodelan dan validasi dan belum diimplementasikan secara menyeluruh, sehingga outcome dari model ini masih belum dapat dipaparkan.

Model dari sistem yang dibangun secara spesifik ditujukan untuk para guru dan siswa sekolah dasar yang membantu proses pemahaman dalam berbahasa mandarin dan pengayaan terutama dalam aritmatika. Sistem yang dibangun bukan hanya menampilkan materi secara statis tetapi juga menjadi media untuk saling bertukar materi ataupun media pengajaran antar guru ataupun pengajar bahasa Mandarin baik dalam ataupun antar sekolah. Sehingga tidak tertutup kemungkinan bahwa materi dapat berkembang dan disesuaikan sesuai dengan kebutuhan dalam sekolah ataupun peserta didik yang ada disana. 
Secara garis besar model dari sistem dapat dijabarkan seperti Gambar 1.

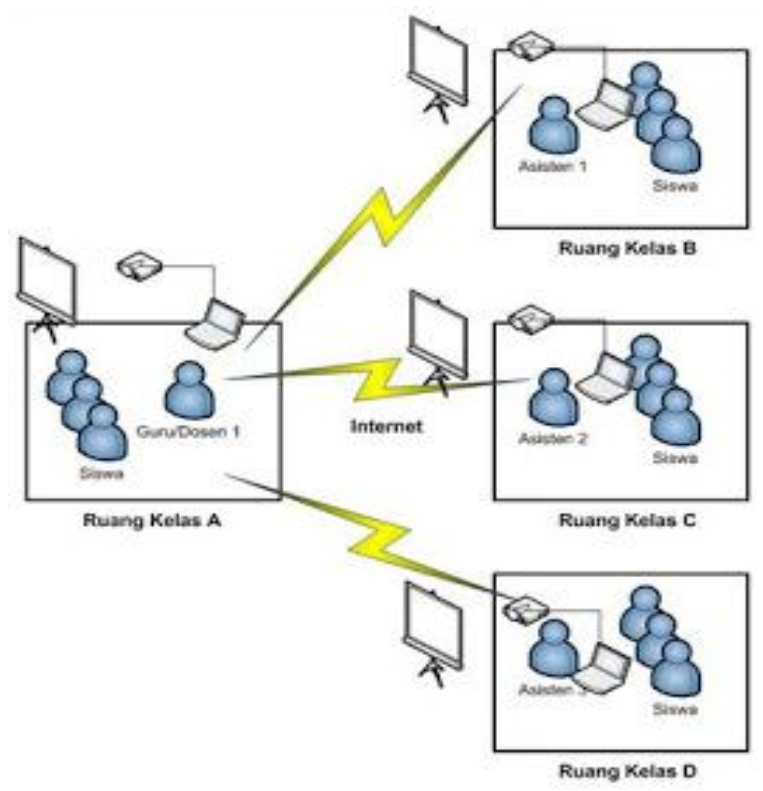

Gambar 1. Skema dari sistem yang dibangun

Dari Gambar 1 dapat dijabarkan sebagai berikut: guru pada ruang kelas $\mathrm{A}$, melakukan update materi ke dalam sistem berupa pengayaan dan soal latihan, maka guru lain di kelas B, C, dan D, juga dapat melihat perubahan yang dilakukan oleh pengajar di kelas A. Meskipun para guru dapat dengan mudah melakukan perubahan atau update dari materi, tetapi secara garis besar materi yang ditampilkan sudah dibagi berdasarkan kurikulum yang ada, sehingga perubahan yang dilakukan haruslah mengacu pada aturan dan standart yang ada yang sudah tercantum dalam buku pembelajaran yang dipergunakan oleh para siswa.

Disini maksud dan tujuannya adalah saling berbagi dan memperkaya materi satu sama lain sehingga para guru juga dapat belajar antara satu sama lain dalam mengembangkan kompetensi proses belajar mengajarnya. Lebih jauh lagi sistem ini diharapkan mampu menjadi kelas virtual dan sekaligus bank data pengetahuan, sehingga apabila ada guru baru yang akan mengajar tidak akan kesulitan untuk mencari ataupun mengetahui materi yang akan diajarkannya.

Secara teknis akan dibangun dengan memanfaatkan HTML 5 sebagai interfacing di yang mampu diakses dengan mudah melalui berbagai browser pada perangkat pembelajar. Kemudian dari sisi server sistem dibangun dengan memanfaatkan bahasa PHP dan server MySQL sebagai penyimpan data. Lebih lanjut untuk repository data menggunakan jaringan FTP. Kesemuanya itu akan diletakkan di web server yang dapat diakses kapanpun dan dimanapun melalui jaringan internet pada perangkat mobile pembelajar. Lebih jauh lagi proses komunikasi yang dilakukan dalam sistem dilakukan dengan mengirimkan paket data melalui jaringan internet. Pengiriman paket data dapat melalui jaringan layanan data seperti EDGE, HSDPA, ataupun EVDO, yang secara langsung terhubung ke internet dan mengakses server data. Kemudian hasil tersebut akan dikirimkan kembali ke perangkat pengguna sehingga bisa menampilkan materi baik berupa animasi ataupun multimedia pembelajaran yang dimaksudkan untuk lebih memperjelas informasi pada bahan ajar siswa seperti buku ataupun penjelasan langsung dari guru pengampu.

\section{Model Pembelajaran}

Model pembelajaran ini secara spesifik ditujukan untuk siswa pada jenjang pendidikan sekolah dasar. Dengan target pengguna adalah para pendidik dan peserta didik dalam lingkungan pendidikan dasar atau sederajat. Tetapi materi tersebut tidak menutup kemungkinan untuk khalayak umum yang juga ingin mempelajari hal tersebut dari yang paling dasar.

Materi yang akan diberikan akan dicluster atau dikelompokkan berdasarkan tema (tematis) sehingga memudahkan pemahaman atas masing-masing subject. Pada setiap tema kompetensi yang hendak dicapai adalah kompetensi terhadap pemahaman percakapan atau membaca, kemampuan menulis beberapa huruf dasar yang sering digunakan, serta mendengarkan.

Adapun skema dari model pembelajaran tematik yang dimaksud dapat diilustrasikan pada gambar 2.

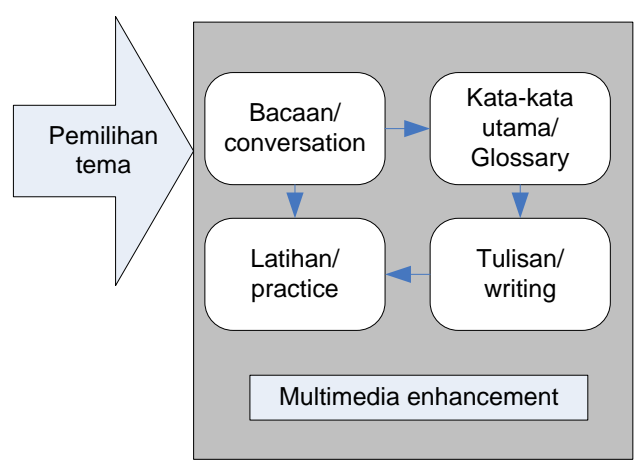

Gambar 2. Skema pembelajaran tematis

Berdasarkan gambar 2, dapat dipaparkan model pembelajaran sebagai berikut; Setiap pembelajar memulai materi dengan materi yang sudah dikelompokkan sebelumnya dan sesuai dengan level kemampuan. Pembelajar akan dihadapkan dengan materi bacaan pertama, dimana pada bacaan tersebut 
akan diberikan node untuk setiap glossary ataupun vocabulary yang akan dijelaskan kemudian. Kemudian pembelajar dapat melanjutkan ke materi bacaan kedua, dimana juga masih dalam satu tema tetapi berbeda subject ataupun jenis seperti percakapan ataupun narasi. Materi bacaan akan disajikan dalam 3 jenis yaitu ditulis dalam karakter Hanzi, Pinyin dan dalam bahasa Indonesia.

Di setiap materi bacaan tersebut para pembelajar dapat mengakses sistem untuk mendapatkan multimedia enhancement sehingga memperjelas isi dari materi yang diperlukan. Hal ini juga mampu melatih pendengaran dan memberikan ilustrasi yang diperlukan untuk memudahkan pemahaman.

Kemudian dari masing-masing materi bacaan akan dikumpulkan setiap glossary yang ada dan akan dibahas masing-masing makna dan pengucapannya. Disini akan juga dijelaskan dalam bentuk Hanzi dan Pinyin beserta penjelasan masing-masing kata yang diperlukan. Disini manfaat dari sistem adalah memperjelas pelafalan dan intonasi dari setiap kata yang dijelaskan.

Setelah mempelajari makna dan intonasi yang ada tahapan berikutnya adalah pembelajar dituntun untuk dapat menuliskan kembali beberapa huruf dasar yang diperlukan. Setiap huruf di dalam bahasa Mandarin memiliki stroke order yang berbeda dan setiap urutan adalah mutlak dan tidak bisa digantikan. Disini peran dari sistem ini mampu menampilkan animasi bagaimana menuliskan tiap-tiap huruf dan urutan dari goresan yang diperlukan. Siswa juga dapat mencoba menuliskan apa yang telah dipelajari dan nantinya sistem akan dapat mengukur seberapa jauh ketepatan siswa dalam menggoreskan huruf tersebut dalam bahasa Mandarin.

Terakhir pembelajar diminta untuk menguji kompetensi dari materi yang telah dipelajari, dimana ada berbagai jenis test yang memungkinkan untuk diambil. Untuk tahapan evaluasi ini, sistem hanya berfungsi sebagai support media yang membantu memperjelas isi soal seperti mengucapkan kembali conversation yang ada ataupun menampilkan gambar yang diperlukan.

Dengan adanya tahapan yang jelas dan dukungan media yang membantu diharapkan penyerapan materi dapat lebih optimal dan menarik, serta bisa mendorong motivasi pembelajaran sepanjang hayat atau lifelong learning [5].

\section{TESTING DAN IMPLEMENTASI}

Metode yang digunakan dalam menguji coba sistem ini adalah dengan model Blackbox testing. Dimana sistem diuji coba dengan berbagai kemungkinan terjadinya error.
Adapun tampilan awal dari program yang dibangun beserta modulnya dapat dilihat pada gambar 3 dan gambar 4. Proses pengujian dilakukan mulai dari proses login hingga menampilkan materi sesuai dengan tema yang telah dipilih oleh pembelajar. Setelah menentukan tema segala aktifitas kegiatan pembelajaran akan disimpan dan dapat ditelusuri kembali. Hal ini berguna untuk mengetahui perkembangan dari proses belajarnya.

Setelah pembelajar memilih course yang sesuai dengan tema, maka akan ditampilkan materi yang terdiri dari empat (4) macam bagian yang meliputi: bacaan (conversation), kata-kata utama (glosary), tulisan (writing) dan juga evaluasi dari ke semua kompetensi yang dipaparkan. Pada saat penampilan materi para pembelajar juga mendapatkan dukungan dari multimedia seperti audio dan video. Dukungan multimedia tersebut membantu pembelajar dalam menginterpretasikan materi yang dipaparkan, dan juga mampu membantu dalam memberikan contoh pengucapan yang benar. Sebagai contoh tampilan materi yang disajikan dapat ditilik pada gambar 5 .

Setelah pembelajar menyelesaikan materi yang disajikan berikutnya adalah practice atau model evaluasi. Adapun model evaluasi yang disediakan di sistem bukan hanya berupa inputan statis tetapi juga bisa berupa multimedia seperti audio, video maupun menulis dengan modul handwriting. Sebagai contoh tampilan evaluasi dengan audio dapat dilihat pada gambar 6 .

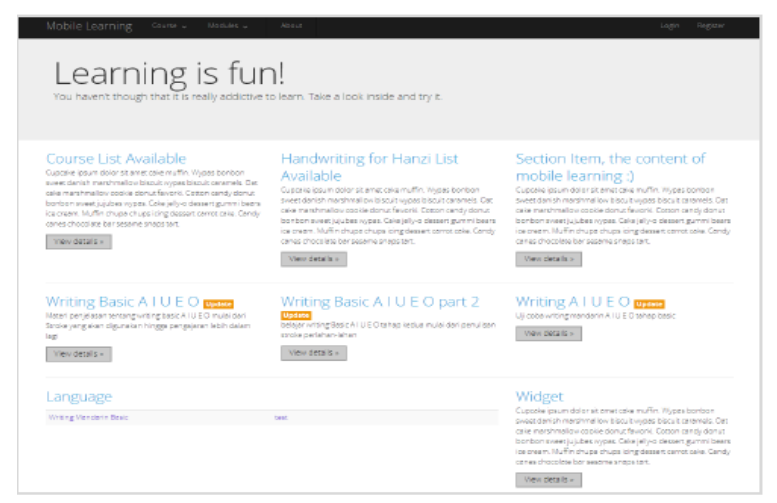

Gambar 3. Tampilan awal program

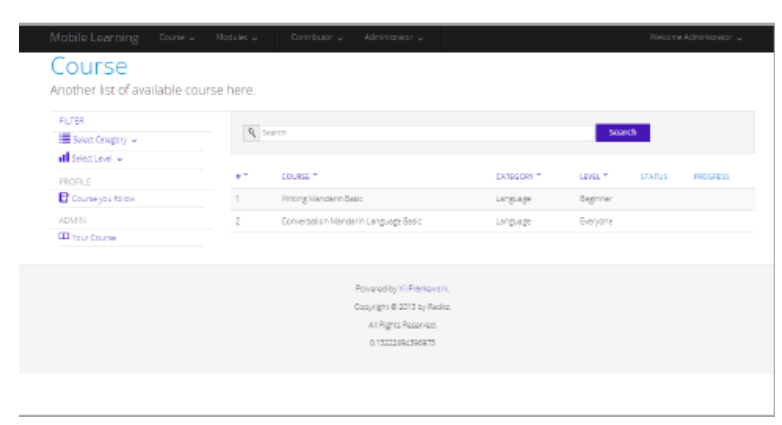

Gambar 4. Tampilan list course program 


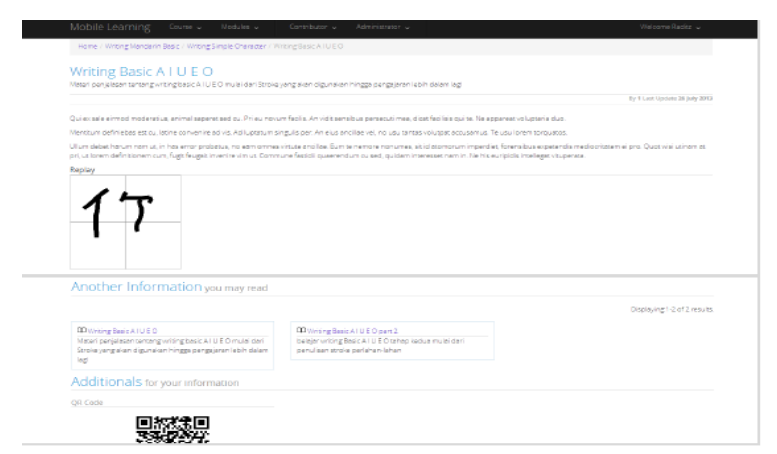

Gambar 5. Tampilan materi yang disajikan

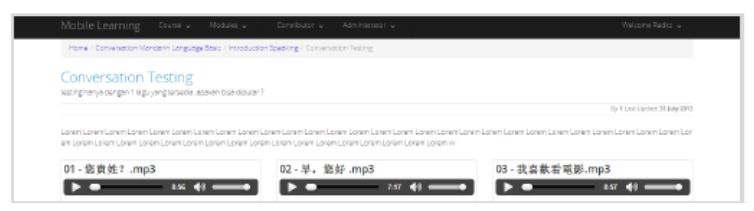

Gambar 6. Tampilan practice dengan audio

Faktor yang terpenting dalam ujicoba ini adalah pada akurasi dan stroke order dari fitur pattern recognition yang digunakan oleh pembelajar dalam menuliskan huruf (handwriting) dalam bahasa Mandarin. Adapun metode dari pattern recogniton dalam medeteksi hasil handwriting dalam program ini adalah menggunakan pendekatan model Haar Classifier. Dimana seperti yang telah disampaikan diatas penulisan dalam bahasa Mandarin selain memperhatikan bentuk tulisannya, dalam proses penulisannya memiliki urutan dalam goresannya (stroke order), dimana dalam bahasa Mandarin memiliki sembilan jenis urutan dan aturan dalam penulisannya. Untuk lebih jelasnya dapat dilihat tampilan antar muka daripada penulisan dalam bahasa Mandarin pada gambar 7 .

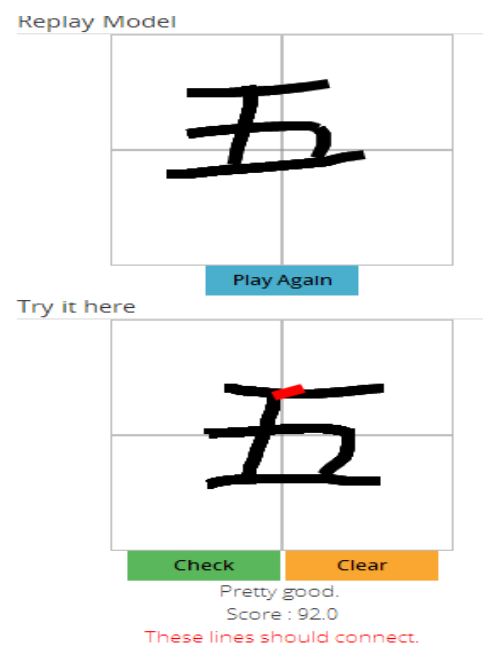

Gambar 7. Tampilan modul handwriting practise

Secara singkat dapat dilihat bahwa pada gambar 7 Untuk kolom yang diatas berfungsi untuk menampilkan animasi urutan dari goresan (stroke order) dari huruf ataupun angka dalam bahasa Mandarin. Kemudian pada kolom kanan difungsikan sebagai media ujicoba dari pembelajar dalam menuliskan kembali apa yang telah dipelajari. Dalam proses evaluasi tersebut sistem secara otomatis harus mampu mendeteksi urutan dari goresan (stroke order) dan juga posisi bentuk dari tulisan yang dituliskan kembali. Dimana pada proses tersebut akurasi dari peletakan posisi tulisan dan urutan kemudian akan diberi nilai yang merepresentasikan ketepatan dari penulisan huruf itu kembali.

Dari hasil ujicoba yang dilakukan oleh tiga puluh orang responded, dapat disimpulkan bahwa semua fitur dari sistem pembelajaran ini mampu difungsikan secara baik dan sesuai. Dalam pengertian seluruh fitur sudah bebas dari error dan dapat dipergunakan sebagaimana mestinya serta mampu memberikan pesan bantuan yang mampu menuntun pengguna dalam menggunakan sistem ini.

Berkaitan dengan kemampuan adaptasi penggunaan sistem ini dapat dimodelkan dengan metode Technology Acceptance Model (TAM). Metode TAM, mampu memberikan gambaran tentang kemampuan responden berkaitan dengan daya serap dan penggunaan dari suatu model teknologi. Hasil dari TAM model ini selanjutnya dianalisa lebih lanjut menggunakan Structural Equation Model (SEM). Sesuai dengan aturan dari SEM, jumlah sample yang digunakan adalah siswa SD di kelas 5 dan 6 dari 2 sekolah swasta di Surabaya dan Lamongan. Adapun jumlah dari sample ditentukan oleh formula sebagai berikut:

$n i=\frac{N i}{N} X n$

Dimana dalam populasi sample tersebut digunakan parameter pretest dan posttest sebagai tolak ukurnya. Semua proses pengujian hypotesis ini menggunakan program Amos 7.0, dan SPSS versi 15.0. Proses testing ini dilakukan dengan path coefficients dan p-value pada level 0.05 .

Dari hasil analisa dengan SEM, didapatkan nilai Critical Ratio $(C R)$ sebesar 6.015, dari nilai yang didapatkan dapat disimpulkan bahwa sistem ini memberikan respond yang positif dari responden. Hal ini berkenaan dengan pemanfaatan media ini sebagai pendukung pembelajaran dan membantu dalam memvisualisasikan materi kepada siswa atau peserta didik, serta mempermudah para pengajar dalam mencari dan membagikan materi ajar.

\section{KESIMPULAN}

Tujuan utama dari sistem ini adalah membangun sebuah sistem pembelajaran yang mampu menjembatani kesulitan dalam belajar bahasa 
Mandarin khususnya dalam pelafalan dan intonasi nada, yang sangat sulit untuk dijelaskan dalam media cetak.

Letak dari kontribusi sistem yang akan dibangun adalah pada kompetensi pedagogik bagi pengajar sehingga memudahkan pemahaman pagi peserta didik terutama dalam mendengarkan (listening) sehingga mempermudah pembelajar dalam menginterpretasikan materi pembelajaran dengan baik. Selain itu sistem ini dapat membantu pemahaman dalam penulisan huruf dengan menampilkan animasi urutan goresan untuk tiap huruf. Sedangkan untuk kasus pemahaman percakapan sistem juga mampu memberikan video dan ilustrasi sehingga pembelajar mampu memahami dan merasakan suasana yang dimaksudkan dalam buku teks yang dimiliki oleh siswa.

Sistem dibangun dengan menyadur teknologi E-learning dengan harapan mampu memberikan sebuah pengalaman dan kemudahan baru bagi para pembelajar tanpa terkendala konstraint waktu dan tempat (ubiquitous learning) Sehingga diharapkan sistem ini mampu memotivasi untuk pembelajaran berkelanjutan dan tiada henti sepanjang hayat.

Hasil dari penelitian ini memberikan respond yang positif. Dikarenakan pembelajar memiliki sebuah model interaksi baru yang lebih menarik dan mudah dalam penggunaannya dan hal ini sejalan dengan penelitian yang dilakukan sebelumnya oleh Ercan, tentang pemanfaatan teknologi informasi dalam pembelajaran [2].

Sistem yang dibangun hanya bersifat supplemental dan tidak mampu menggantikan fungsi pembelajaran konvensional di kelas secara penuh.

\section{DAFTAR PUSTAKA}

[1] Abell, C., \& Currie, G. Internal and external pictures. Philos Psychol, 12, 1999. pp. 429- 445.

[2] Ercan, T. Benefits of semantic approach in the learning environment. Procedia - Social and Behavioral Sciences, 28(0), 2011. pp. 963-967. doi: 10.1016/j.sbspro.2011.11.177

[3] Hennig-Thurau, T., \& Klee, A. The impact of customer satisfaction and relationship quality on customer retention: A critical reassessment and model development. Psychology and Marketing, 14(8), 1997. pp. 737-764. doi: 10.1002/ (sici)1520-6793(199712)14:8<737::aidmar2>3.0.co;2-f

[4] He, Q., Valcke, M., \& Zhu, C. Promoting a special learning environment for second language learning in a Chinese rural primary school. Procedia - Social and Behavioral Sciences, 12(0), 2011. pp. 137-144. doi: http://dx.doi.org/10.1016/j.sbspro.2011.02.019

[5] Hosseini Bidokht, M., \& Assareh, A. Life-long learners through problem-based and self directed learning. Procedia Computer Science, 3(0), 2011. 1446-1453. doi: 10.1016/j.procs. 2011.01.028

[6] Huifen, Z. Zhang Laoshi Jiao Hanzi : Hanzi Shi Xie Keben (Shang). Beijing: Beijing Yuyan Daxue Chuban She. 2007.

[7] Lau, K. L. Chinese language teachers' perception and implementation of self-regulated learning-based instruction. Teaching and Teacher Education, 31(0), 2013. pp. 56-66. doi: http://dx.doi.org/10.1016/j.tate.2012.12.001

[8] Min, M. A. The Reflection on the Domestic Research Status of Language Learning Strategies Used by Foreign Students Learning Chinese. Physics Procedia, 25(0), 2012. pp. 2309-2314. doi: http://dx.doi.org/10.1016/j. phpro.2012.03.389

[9] Mohammadi, N., Ghorbani, V., \& Hamidi, F. Effects of E-learning on language learning. Procedia Computer Science, 3(0), 2011. 464468. doi: http://dx.doi.org/10.1016/j.procs. 2010.12.078

[10] Müller, C. Experiences and evaluation of a blended learning concept for learning Chinese in higher education. Procedia - Social and Behavioral Sciences, 34(0). 2012. pp. 158-163. doi: http://dx.doi.org/10.1016/j.sbspro.2012.02 .032

[11] Ozcelik, E., \& Acarturk, C. Reducing the spatial distance between printed and online information sources by means of mobile technology enhances learning: Using 2D barcodes. Computers \& Education, 57(3), 2011. pp. 20772085. doi: 10.1016/j.compedu.2011.05.019

[12] Ozdamli, F., \& Cavus, N. Basic elements and characteristics of mobile learning. Procedia Social and Behavioral Sciences, 28(0), 2011. 937-942. doi: 10.1016/j.sbspro.2011.11.173

[13] Reber, A. (1976). Implicit learning of synthetic languages: The role of instructional set. $J$ Exp Psychol Hum Learn Mem, 2, 88 - 94.

[14] Sirmaci, N. The relationship between the attitudes towards mathematics and learning styles. Procedia - Social and Behavioral Sciences, 9(0), 2010. 644-648. doi: http://dx. doi.org/10.1016/j.sbspro.2010.12.211

[15] Tarmizi, M. A. A., Tarmizi, R. A., \& Mokhtar, M. Z. B. Humanizing Mathematics Learning: Secondary Students Beliefs on Mathematics Teachers' Teaching Efficacy. Procedia - Social and Behavioral Sciences, 8(0), 2010. 532-536. doi: http://dx.doi.org/10.1016/j.sbspro.2010.12. 073

[16] Zhou, G. Dui "Zhongxinyu lilun he hanyu de DeP" yi wen de zhiyi. Dangdai Yuyanxue, 2005. 